\title{
Notes on the distribution of Caridina sulawesi, an endemic freshwater shrimp from Sulawesi, Indonesia
}

\author{
Diky Dwiyanto ${ }^{1,3^{*}}$, Achmad Farajallah', and Annawaty A nnawaty ${ }^{2}$ \\ ${ }^{1}$ Department of B iology, Faculty of M athematics and Natural Science, 16680 IPB University Gedung Biologi Jalan A gatis K ampus \\ IPB Dramaga, Bogor, Indonesia \\ ${ }^{2}$ Department of Biology, Faculty of Sciences, 94119 Tadulako University Jalan Raya Soekarno-Hatta Kampus B umi Tadulako Tondo, \\ Palu, Indonesia \\ 3Zoological Community of Celebes (ZCC), 94118 Jalan K amboja, Palu, Indonesia
}

\begin{abstract}
Caridina sulawesi Cai and $\mathrm{Ng}, 2009$, an endemic freshwater shrimp, has been described based on the type locality in M aros, South Sulawesi. Surprisingly, this species was reported from two rivers in Central Sulawesi. Here, we provided the data about ecological aspects and the recent distribution of the species on Sulawesi Island. The specimens were collected using a hand net in 2018 and 2019, from a small natural spring in Bobo and two creeks in Napu. Water temperature varied between 17 to $22^{\circ} \mathrm{C}$. Our finding shows $C$. sulawesi inhabited almost all freshwater habitat exclude lake system, with high variation in elevation and water temperatures.
\end{abstract}

\section{Introduction}

Genus Caridina H. Milne Edwards, is the most widespread freshwater shrimp from family A tyidae. This genus contains more than 300 valid species and occurs from the A frica to Indo-Pacific region [1]. The members of this genus have at least two life strategies, i.e., prolonged type -required saline water for larval development, and abbreviated type -larval fully developed in freshwater [2]. In the tropical islands, such as Sulawesi, the latter type, called as landlocked type, can be found both on habitat lacustrine (lakes) and riverine (rivers or streams) $[3,4]$.

The endemic shrimp genus Caridina from Sulawesi and small islands around comprise of 34 species. M any studies only focussed in the ancient lakes (e.g. Poso Lake and $M$ alili Lake System), therefore it double raise the number of lacustrine species in those areas [5]. A total of 14 riverine species has been documented on this Island. Although the research on freshwater riverine endemic shrimp genus Caridina in Sulawesi was started about some centuries ago, intensive studies have begun in recent decades. The taxonomic issues of riverine endemic Caridina have been discussed by several authors [4-7], but the comprehensive data about their ecology and distribution is very lacked. One of riverine endemic shrimp that has a unique distribution pattern in the island is Caridina sulawesi.

Caridina sulawesi Cai and $\mathrm{Ng}, 2009$ firstly been described based on type specimen from Sungai Beru, Kappang, in M aros, South Sulawesi [7]. Previously, the distribution of this species has only known restricted in several locations in the southern and southeast arm of Sulawesi $[4,7]$.

Surprisingly, this species was reported from two rivers in Central Sulawesi namely Poboya (PN) and Toranda (TR) $[8,9]$. The recent study revealed of $C$. sulawesi in a small natural spring in Bobo and two creeks in Napu, Central Sulawesi. Here, we provided the data about ecological aspects and the recent distribution of the species on Sulawesi Island.

\section{Materials and methods}

There is a natural spring which is located on the cacao plantation in B obo village, Sigi. It is located about $30 \mathrm{~km}$ from Palu, the capital city of Central Sulawesi, Indonesia. Two other sites of creeks were located in Watumaeta and Watutau Village, Lembah Napu, Poso and flow towards the south joining with Lariang River. All sites are close to the border of Lore Lindu National Park (LLNP) (Fig. 1), the largest conservation area in Central Sulawesi. This area comprises sub-mountain to mountain zone, with altitude ranged from 250 to $2340 \mathrm{~m}$ above sea level [10]. The sampling from Bobo natural spring was conducted during a field course of Department Biology, Tadulako University in 2018 while the samples taken from the two other sites, Watumaeta and Watutau, were conducted during fieldwork by Zoological Community of Celebes (ZCC) in 2019.

\footnotetext{
* Corresponding author: dikydwiyanto@gmail.com
} 


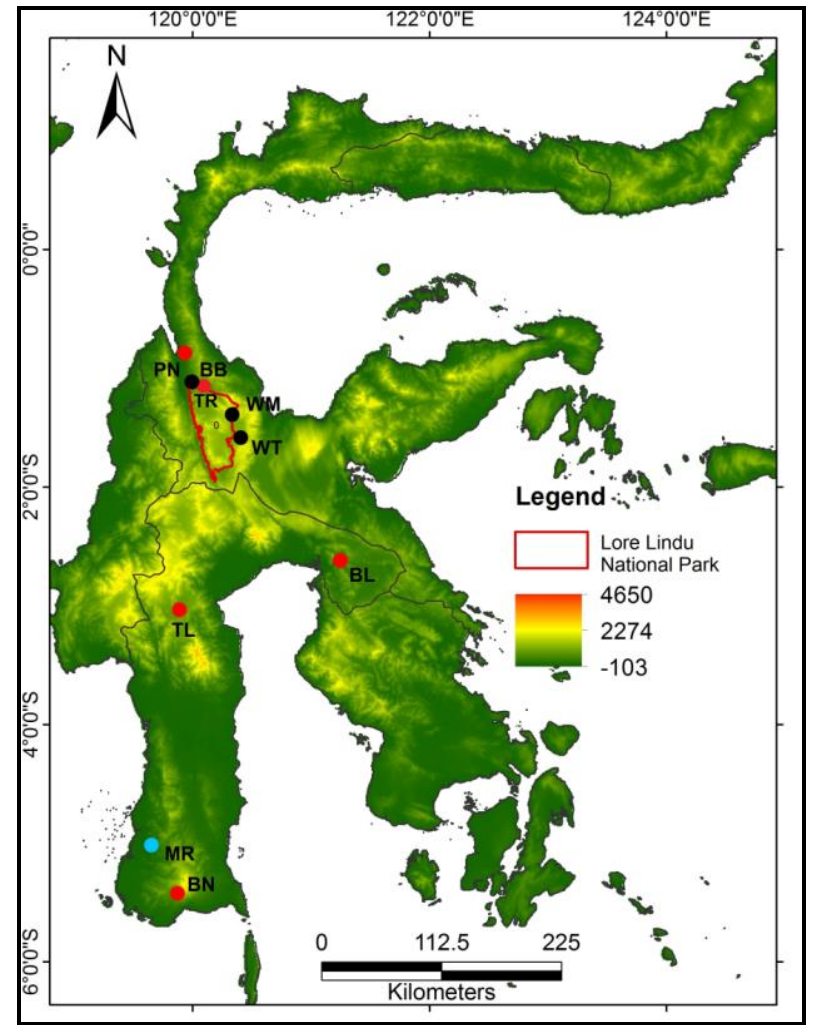

Fig. 1. Study sites and distribution of Caridina sulawesi on Sulawesi Island, Indonesia. Black dot shows the study sites close to the border of TNLL; red dot shows the distribution based on previous studies by several authors; blue dot shows type locality of the species, in Sungai B eru Kappang, Maros. ( $\mathrm{PN}=$ =Poboya; $\quad \mathrm{TR}=$ Toranda; $\mathrm{BL}=\mathrm{B}$ al ambano; $\mathrm{TL}=$ Tilanga; $\mathrm{BN}=\mathrm{B}$ antaeng; $\quad \mathrm{MR}=\mathrm{M}$ aros; $\quad \mathrm{BB}=\mathrm{B}$ obo; $\quad \mathrm{WM}=\mathrm{W}$ atumaeta; $W T=W$ atutau). The color of the map displays altitudinal differences ( $m$ asl) in each site.

The specimens were collected using a hand net and preserved in ethanol $96 \%$. All of the materials used for identification and eggs measurement were kept in the Laboratory of Animal Biosystematic and Evolution, Department of Biology, Faculty of Sciences, Tadulako University, Palu, Indonesia. The eggs size of ovigerous females were measured from the longest and shortest axis [11] using a digital caliper $(0.2 \mathrm{~mm})$. Water temperature measurement was made using a mercury thermometer.
For habitat description, both substrate [12] and microhabitat were recorded at each site. Coordinates and altitude of all sites in this study were taken using GPS (Global Positioning System) Garmin eT rex 10 (Garmin $L t d$.) and rest sites were acquired basis on the record of specimens localities in the studies by several authors [4,7-9]. The distribution map was prepared using A rcM ap 10.3 based on Indonesia elevation data from DIVA-GIS (www.diva-gis.org).

\section{Results and discussion}

\subsection{Morphology of Caridina sulawesi}

Caridina sulawesi has a semi-transparent body-color with brown dots scattered on the cephalothorax to the abdomen (Fig. 2). This species, like other members of riverine species, has a less striking coloration compared to the lacustrine species in Lake Poso and M alili Lakes System. The body coloration of atyid shrimps, generally affected by their dwelling substrate (Daisy W ow or 2017 pers. comm.).

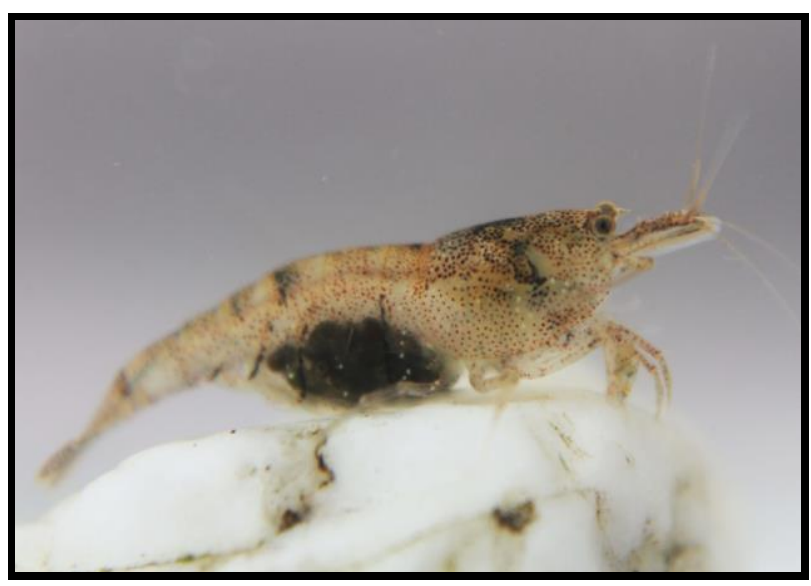

Fig. 2. O vigerous female of Caridina sulawesi from Watutau Creeks, Central Sulawesi (not to scale). The figure show color pattern, morphology of rostrum and eggs of the species (Photo by D. Dwiyanto).

Table 1. Sampling sites and habitat descriptions of Caridina sulawesi in Central Sulawesi.

\begin{tabular}{ccccccc}
\hline Locations & $\begin{array}{c}\text { Number of } \\
\text { individual }\end{array}$ & Habitat & Substrate & M icrohabitat & $\begin{array}{c}\text { Water } \\
\text { Temp. }\left({ }^{\circ} \mathrm{C}\right)\end{array}$ & $\begin{array}{c}\text { Elevation } \\
(\mathrm{m} \text { asl })\end{array}$ \\
\hline $\begin{array}{c}\text { Bobo V illage, Sigi Central } \\
\text { Sulawesi }\end{array}$ & 78 & $\begin{array}{c}\text { Natural } \\
\text { spring }\end{array}$ & Silty sand & L eaf litter & 22 & 752 \\
$\begin{array}{c}\text { W atumaeta Village, Poso, Central } \\
\text { Sulawesi }\end{array}$ & 4 & Creek & $\begin{array}{c}\text { Coarse } \\
\text { sand }\end{array}$ & L eaf litter & 18 & 1197 \\
$\begin{array}{c}\text { Watutau V Village, Poso, Central } \\
\text { Sulawesi }\end{array}$ & 49 & Creek & Silty sand & M acrophytes & 17 & 1214 \\
\hline
\end{tabular}


Morphologically, our materials are quite similar to the original description of $C$. sulawesi described by $C$ ai and $\mathrm{Ng}$ 2009. The specimens have very short rostrum, reaching near to or reach end of basal segment of antennular peduncle. Rostrum unarmed or armed dorsally with 2-5 teeth. The first pereiopod with carpus excavated anteriorly, about 1.6-1.8 times as long as wide. Second pereiopod with slender carpus, about 5.5 times as long as wide and 1.3 times as long as chelae.

\subsection{Ecology of Caridina sulawesi}

In this study, Caridina sulawesi was found from both habitat in the surface water of natural spring and creeks (Table 1). Previous studies have shown this species only reported from river in both surface and subterranean water [4,7-9]. The highest number of individual was obtained in Bobo natural spring, and the lowest was recorded in creek of W atumaeta $V$ illage.

The different numbers of these individuals might be correlated with the different number of sampling in each site and substrates. This species was observed as sand substrate dwellers and prefer silty sand. Our finding is different from two other populations in Central Sulawesi, where they found this species in mossy and rocky substrates $[8,9]$. In contrast to lacustrine species, where the species composition is strongly affected by the type of substrates (hard or soft substrate) [5], riverine species of Caridina can be found in both soft and hard substrate. The microhabitat of $C$. sulawesi was common among piles of leaf litter and dead branches of Theobroma cacao, Areca catechu and Dillenia cf. serrata (B obo and W atumaeta sites) and macrophytes in W atutau site. Leaf litter in the tropical stream ecosystem is one of the favorable microhabitats for many freshwater invertebrates [13] because it provides a significant potential food resources. For atyid shrimps, their cheliped equipped by setae which makes it easy to scavenge microbial on the leaf litter surface [14].

The water temperature from all sites varied between 17 to $22^{\circ} \mathrm{C}$, and it correlated with the altitude of the sites (Table 1). Bobo natural spring has the the highest temperature with elevation only $752 \mathrm{~m}$ above sea level while creek in Watutau, Napu, has the lowest water temperature with highest elevation up to $1214 \mathrm{~m}$ above sea level. Caridina sulawesi has also been found in temperature 22 to $24^{\circ} \mathrm{C}$ [8]. In the $\mathrm{N}$ apu site, there are also two streams nearby Watutau creek with water temperature between 15.2 to $16^{\circ} \mathrm{C}$. We found no shrimp in these sites even though we did much effort to find it, which might because this species could not tolerate the temperature below $17^{\circ} \mathrm{C}$. Temperature is one of the physical factors confining the distribution of freshwater shrimp. For example, C. kaili in Lake Lindu, Central Sulawesi, was only found in the inlet which has a maximum temperature of $23^{\circ} \mathrm{C}$ and never been found in the temperature above it [15].

\subsection{Egg size of Caridina sulawesi}

The egg size of $C$. sulawesi was greater than two other previous reports (Table 2). It was suggested that the reproductive biology of $C$. sulawesi belongs to the complete suppression larvae type [16], which spend their entire life in freshwater habitat. However, the eggs size of $C$. sulawesi are still smaller than $C$. kaili in Lake Lindu System (1.20-1.50 x 0.80-1.00 mm) [17] and Lancaris singhalensis Ortmann, from Sri Lanka $(1.80 \mathrm{x}$ $1.24 \mathrm{~mm}$ ) with complete development larvae (as Caridina singhalensis [18]). Generally, the large egg sizes have shorter larval developmental stages, either two [18] or three stages [19].

Table 2. Eggs size variation of Caridina sulawesi interpopulation.

\begin{tabular}{ccc}
\hline Locations & Eggs Size $(\mathrm{mm})$ & Sources \\
\hline $\begin{array}{c}\text { Maros, Southern } \\
\text { Sulawesi }\end{array}$ & $0.90-1.00 \times 0.55-0.65$ & $\begin{array}{c}\text { Cai and } \mathrm{Ng}, \\
2009\end{array}$ \\
$\begin{array}{c}\text { Palu, Central } \\
\text { Sulawesi }\end{array}$ & $0.80-1.00 \times 0.40-0.80$ & $\begin{array}{c}\text { M ulyati } \text { et al. } \\
2016\end{array}$ \\
$\begin{array}{c}\text { Bobo Village, Sigi } \\
\text { Central Sulawesi } \\
\text { Watutawu }\end{array}$ & $1.18-1.28 \times 0.43-0.81$ & Present study \\
$\begin{array}{c}\text { Village, Poso, } \\
\text { Central Sulawesi }\end{array}$ & $1.10-1.24 \times 0.75-0.83$ & Present study \\
\hline
\end{tabular}

\subsection{Distribution of Caridina sulawesi}

Caridina sulawesi was found in the three sites, i.e., B obo (BB), Watumaeta (WM) and WT (Watutau). This finding has expanded the distribution range of this species in Central Sulawesi which previously only reported in Toranda River, near Bobo site, and Pondo River, near Palu City $[8,9]$. Based on their type locality in Sungai Beru, Kappang, Maros (MR) (Fig. 1), C. sulawesi is the only member of endemic shrimp genus Caridina with wide distribution, from southern to the central part of Sulawesi. This species may be lived sympatrically with other riverine species, i.e., C. leclerci, $C$. longifrons, C. parvidentata, and C. pareparensis, according to their locality in Maros (for detail please refer material examined in $[6,7]$ ) (Table 3 ).

In the eastern part, this species was found only in Balambano (BL), road from Malili to Sorowako (as Sungai Balambang in [7]). It has been questioned how could $C$. sulawesi distributed in this part. We hypothesized that the distribution of $C$. sulawesi might be affected by the geological process when Sulawesi Island formed in the past. Many taxa in Sulawesi Island have been distributed by dispersal events after $M$ akassar strait formed which separated Sulawesi and Borneo islands [20]. However, some future studies, such as phylogeography analysis, are needed to show the biogeography pattern of this species. 
Table 3. Distribution list of Caridina riverine species endemic to Sulawesi and small surround islands (based on [4]), *) Present study; $(8,9)$.

\begin{tabular}{|c|c|}
\hline Species & Distribution \\
\hline 1. Caridina acutirostris Schenkel 1902 & Inlet of Lake Poso \\
\hline 2. Caridina boehmei $\mathrm{K}$ lotz \& von Rintelen 2013 & Tomori A rea, Central Sulawesi \\
\hline 3. Caridina butonensis K lotz \& von Rintelen 2013 & Pulau Buton, near South-Eastern Sulawesi \\
\hline 4. Caridina kaili A nnawaty \& W owor 2015 & Inlet of Lake Lindu \\
\hline 5. Caridina laroeha $\mathrm{K}$ lotz \& von Rintelen 2013 & L aroeha A rea, Central Sulawesi \\
\hline 6. Caridina leclerci Cai \& Ng 2009 & M aros, South Sulawesi \\
\hline 7. Caridina longifrons $\mathrm{Cai} \& \mathrm{Ng} 2007$ & M aros, South Sulawesi \\
\hline 8. Caridina mahalona Cai et al. 2009 & River in M alili Lake System \\
\hline 9. Caridina opaensis R oux 1904 & A opa A rea, South-E astern Sulawesi \\
\hline 10. Caridina pareparensis De M an 1892 & Several locations in South Sulawesi \\
\hline 11. Caridina parvidentata Roux 1904 & Several locations in South Sulawesi \\
\hline 12. Caridina sulawesi Cai \& Ng 2009 & Several locations in South Sulawesi and Central Sulawesi* \\
\hline 13. Caridina schenkeli von Rintelen \& Cai, 2009 & Inlet of Lake Poso \\
\hline 14. Caridina thomasi von Rintelen et al. 2008 & Peleng Island, near L uwuk Peninsula \\
\hline
\end{tabular}

Caridina sulawesi mainly distributed more in the inland water than nearby the estuary (Fig. 1). Their life strategy which supported by landlocked type showed that no longer requires brackish water or sea for larval development. However, they can be found in various altitudinal ranging from the lowland area to the mountain creeks.

\section{Conclusion}

Caridina sulawesi is an endemic shrimp inhabited in almost all freshwater habitat from a small natural spring to rivers, exclude lakes system. Based on their distribution, this species is commonly found in the inland water with high variation in elevation and water temperatures. Caridina sulawesi is widely distributed from southern to the central part of Sulawesi Island. The further study about phylogeography is needed to understand their biogeography on Sulawesi island, even though it may need more effort to find more samples.

We would like to thank the Zoological Community of Celebes (ZCC) staff for their kindly support during fieldwork and Puji Rahayu for help during laboratory work. We are also grateful to Dr. Y ixiong Cai from the $\mathrm{N}$ ational Biodiversity of Singapore for giving the information about the locality of the species and Dr. Daisy Wowor from the Indonesian Institute of Sciences (LIPI) for her valuable comments and suggestions to this manuscript. Finally, the author wishes to thank Dr. Sarah Nila and an anonymous reviewer for their suggestions that greatly helped to improve this paper. This study was partially supported by the M inistry of Research, Technology and Higher Education, through Program "Penelitian Dasar" the Fiscal Year 2019 contract number: 351.v/UN28.2/PL/2019, and Indonesia Endowment Fund For Education (Lembaga Pengelola Dana Pendidikan), M inistry of Finance, R epublic of Indonesia.

\section{References}

1. V. de M azancourt, W. K lotz, G. M arquet, P. K eith, Invertebr. Syst. J 32(6), 1422-1447 (2018) DOI: 10.1071//S18034

2. D. Wowor, Y. Cai, P.K.L. Ng, Crustacea: Decapoda: Caridea. Freshwater Invertebrates of the Malaysian Region. (A cademy of Science, K uala L umpur, 2004)

3. K. von Rintelen, A. Karge, W. Klot, J. Nat. Hist 42(33-34), 2243-2256 https://doi.org/10.1080/00222930802254680

(2008)

4. W. Klotz, K. von Rintelen, Zootaxa 3664(4), 554 570 (2013) DOI: 10.11646/zootaxa.3664.4.8

5. K. von Rintelen, Y. Cai, Raffles Bull. Zool 57(2): 343-452 (2009)

6. Y. Cai, P.K.L. Ng, J. Nat. Hist, 41(25-28), 15871602 (2007) DOI: 10.1080/00222930701458754

7. Y. Cai, P.K.L. Ng, J. Nat. Hist, 43(17-18), 10931114 (2009) https://doi.org/10.1080/00222930902767482

8. H.E. M angesa, F. Fahri, A. A nnawaty. Nat. Sci. J. Sci Tech 5(3), 288-295 (2016)

9. T. Mulyati, F. Fahri, A. A nnawaty, Nat. Sci. J. Sci Tech 5(1), 83-96 (2016)

10. I. M aryanto, M. Y ani, S.M. Prijono, S. Wiantoro, It. J. M ammal 22(1), 167-177 (2011) https://doi.org/10.4404/hystrix-22.1-4480

11. J-Y. Shy, H-T. Lai, H-P. Y u, Crustaceana 74(10), 1159-1168 (2001) 10.1163/15685400152691160

12. C.K. Wentworth, J. Geol 30(5), 377-392 (1922)

13. D. Dudgeon, Freshw. Biol 51(6),1710-1729 (2006) DOI: $10.1111 /$ j.1365-2427.2006.01596.x 
14. Williams, Biotropica 34(4), 616-619 (2002) https://doi.org/10.1111/j.17447429.2002.tb00583.x

15. A. A nnawaty, D. Wowor, A. Farajallah, D. Setiadi, B. Suryobroto, HAYATI J. Biosci 23, 45-50 (2016) DOI: 10.1016/j.hjb.2016.04.001

16. H-T. Lai, J-Y. Shy, Raffles Bull. Zool. Suppl 20, 97-107 (2009)

17. A. Annawaty, D. Wowor, Zootaxa 3957(5), 501519 (2015) D OI: 10.11646/zootaxa.3957.5.1
18. J.A.H. Benzie, P.K. de Silva, J. Crustac. Biol 3(1), 117-126 (1983) D OI: 10.2307/1547857

19. S. Shokita, Bulletin of Science \& Engineering Division, University of Ryukyus. Mathematics \& $N$ atural Sciences 16, 222-231 (1972)

20. B. Stelbrink, C. A lbrecht, R. Hall, T. von Rintelen, Evolution, 66-7, 2252-2271 (2012) DOI: 10.1111/j.1558-5646.2012.01588.x 